\title{
Seeing It from Both Sides: Beyond Bridges in Research-to-Practice
}

\author{
Thomas J. Shindell
}

As the chair of the ASTD Research-to-Practice Committee for three months, I am pleased and excited by all of the possibilities I see within ASTD and within the Academy of Human Resource Development for more significant collaboration. Natural partners, ASTD and the Academy have just begun to explore and engage in the mutually beneficial activities that are possible.

The new ASTD senior director of research, Brenda Sugrue, is the organizational sponsor of the Research-to-Practice Committee. A strong force in developing a new focus and obtaining new resources for the ASTD Research Department, she has been a great partner in identifying the research needs of practitioners. I have also had the opportunity to interview Tony Bingham, the new CEO and president of ASTD, and hear his vision for ASTD and the field of workplace learning and performance (Shindell, 2005a). He sees partnering as key to ASTD's future success.

ASTD, traditionally a practitioner-focused organization, is making a concerted effort to reach out in direct ways to the academic research community. In response to previous suggestions from the Research-to-Practice Committee, ASTD is hosting its first Research-to-Practice Conference-within-a-Conference at its 2005 International Conference and Exposition in Orlando, Florida. In this new activity for ASTD, researchers and scholars will share their research results tailored to the needs of practitioners. ASTD is encouraging researchers, academics, and their students in human resource development (HRD) and workplace learning and performance to be more involved. Graciously, ASTD is making special conference rates available to them. The launch of the new Excellence in Research-to-Practice Awards is particularly exciting. Led by Darren Short and Martin Kormanik, the awards recognize excellence in research-to-practice activities conducted by researchers, practitioners, and collaborative partnerships of researchers and practitioners.

As a former executive director of the Academy, I am pleased and excited by the international scope and membership it has achieved and the four journals (one of which is cosponsored with ASTD) it sponsors. I had the opportunity to interview the current president of the Academy, Larry Dooley, 
and hear his vision for the Academy and the field of HRD (Shindell, 2005b). He strongly echoes a consistent message of encouraging more collaboration between the Academy and ASTD (Dooley, 2004).

Reflecting the Academy's willingness to try new things, this year will see the first practitioner track at the 2005 International Academy meeting in Colorado. Led by Lane Morris and Darren Short, this track of refereed work by practitioners is an opportunity for them to present their research or their tests of current theory, or both. In a far more inclusive and welcoming way, the Academy is reaching out to practitioners, especially scholarly practitioners, as partners.

This partnership of ASTD and the Academy has evolved successfully thus far in spite of communication and trust issues in the past. It still faces a few. Organizational wisdom reminds us that adequate communication and trust are essential to maintaining partnership momentum and avoiding misunderstandings. For example, with adequate communication and trust, seeing the two new conference activities as competition-forcing members of ASTD and the Academy to choose which conference and which activities to attendwould be impossible. Another current misunderstanding involves ASTD's decision to hold no longer one of the two annual ASTD Research-to-Practice Committee meetings at the annual Academy conference. This does not mean, as could be concluded, that ASTD does not want to be involved or partner with the Academy. It means only that given the new Research-to-Practice Conference-within-a-Conference activity, this scheduling is more appropriate for ASTD. In my role as the chair of the ASTD Research-to-Practice Committee, I want to help resolve these and any other communication and trust issues that may arise.

I want the Academy to seize the opportunity it has to play a major role in ASTD's higher education strategy, for the betterment of both fields. The members of the Academy are the same individuals (both researchers and graduate students) with whom ASTD wants to partner directly in its conferences and publications. Reaching out to practitioners even more with direct applications, techniques, and tips based on the invaluable and informative research conducted by Academy members would greatly enhance the research-to-practice agenda.

I want ASTD to take advantage of its opportunity to reach out even more to the Academy's leadership and members (many of whom are also members of ASTD) and more deliberately align their research-to-practice goals, missions, and objectives with those of Academy. ASTD can communicate more clearly how much it truly values its strategic partners and thus increase their mutual trust and respect. As a consequence, the vast network of ASTD members would be more open to the members of the Academy for potential research topics, sites, and test cases. 
In the future, I see ASTD and the Academy jointly sponsoring research-topractice conferences, publications, and awards for the benefit of everyone. These jointly sponsored activities may even include other organizations, like the International Society for Performance Improvement or the Academy of Management. Imagine the potential synergy: links on each other's Web sites, dual organizational memberships, joint research activities, dual sponsorship of a joint research-to-practice committee, endless possibilities, and a profound challenge to go beyond bridges in research-to-practice.

THOMAS J. SHINDELL Chair, ASTD Research-to-Practice Committee

\section{References}

Dooley, L. M. (2004). AHRD and ASTD: Competitors or collaborators? Human Resource Development Quarterly, 15 (4), 359-361.

Shindell, T. J. (2005a). Exploring the future of ASTD: An interview with Tony Bingham. Human Resource Development International, 8 (1), 89-93.

Shindell, T. J. (2005b). Examining the academy's future: An interview with Larry M. Dooley. Human Resource Development International, 8 (1), 94-98. 
